\title{
ISLAMIC HOUSEHOLD FINANCIAL MANAGEMENT IN THE KELURAHAN TANJUNG DUREN AREA, WEST JAKARTA
}

\author{
Islamiah KAMIL and Dewi ANGGRAINI* \\ Dian Nusantara University \\ islamiah.kamil@undira.ac.id; dewi.anggraini@undira.ac.id
}

\begin{abstract}
Islamic family financial management must be based on the principle of belief that the determinant and provider of sustenance is Allah with an intentional effort to meet the needs of the family so that they can worship sincerely so that they have the commitment and priority of halal income that brings blessings and avoids illicit income that brings disaster.The purpose of this activity is to be able understand household financial management from an Islamic point of view, Implement management of spending and consumption patterns from an Islamic point of view The implementation method used is 1). Extension method; used for deliver material in the form of theory. 2). Question and answer method; used to provide opportunities for participants who are not yet clear in their understanding; 3). Demonstration Method; Implementation Islamic spending and consumption patterns4).Exercise/Practice Methods; An example of Islamic household financial management. The result of this activity is the participants' understanding of the three basic principles of managing Muslim household finances, namely: 1) Strive to earn a living that is lawful and thayyib., 2) Efficient and economical and 3) Get used to saving for the hereafter.
\end{abstract}

Keywords: Islamic Finance, Tanjung Duren Barat Village, Principles Muslim Household Financial Management

\section{BACKGROUND}

They forget that every household is the meeting of two individuals who differ in personality and character in a legal marriage bond so that if there is a conflict of course they will resolve it with their own way and point of view. It's not a wise decision if the way out is to leave love or just frantically look for additional income. The best way when finances are not sufficient for the family's needs is to communicate and sit together looking for the best solution. corridor of religion. This is where it is important for married couples to understand the principles of economics and financial management in a household from an Islamic point of view. (Dyah 2011)

Muhammad (2013) Property in Islam is a trust and property of a person. The authority to use it is closely related to the ability (competence) and decency (integrity) in managing assets or in terms of the prudential principle of banking.

Islamic principles teach that "The best of pious (good) assets are managed by people who have pious (trustful and professional) personalities." The right to work in the sense of freedom to do business, trade, produce goods and services to seek Allah's sustenance in a lawful manner is the right of every human being without discrimination between men and women. If we know that women are given by God property rights and freedom to own, then they should also have the right to try and seek sustenance.

Awareness of accountability (ma'uliyah) in the financial sector which includes aspects of income and expenditure management arises because of the belief in audit certainty and supervision from Allah subhanahu wa ta'ala. Islamic family financial management must be based on the principle of belief that the determinant and provider of sustenance is Allah with an intentional effort to meet the needs of the family so that they can worship sincerely so that they have the commitment and priority of halal income that brings blessings and avoids illicit income that brings disaster. In seeking income, Islam does not allow a person to be ngoyo in the sense of trying beyond his ability and being too obsessed so that he sacrifices or neglects other rights both to Allah, himself and his family such as education and attention to children and family. In the management of family finances, it cannot be separated from optimizing the potential of families including children to produce Allah's sustenance. Islam always pays attention to the problem of child growth with the suggestion that children be trained to be independent and earn from their teens in addition to being frugal so that the economic growth of Muslim families can run smoothly which is the meaning of realizing blessings in quantity, Islam forbids parents from spoiling their children so that they grow into parasites. , not independent and dependent on others.

Based on his description above, it is deemed necessary to hold Islamic household financial management in the community by breaking down the problem as follows:

1. How to manage household finances from an Islamic point of view?

2. How is the management of spending and consumption patterns from an Islamic point of view?

After participating in Islamic household financial management activities, participants are expected to be able to:

1. Understanding household financial management from an Islamic point of view,

2. Implementing the management of spending and consumption patterns from an Islamic point of view

Community service in this case is where Islamic household financial management can add insight to wives in helping husbands manage family finances wisely and not deviate from Islamic law. 


\section{METHOD}

The strategic target in this community service is housewives and young women who live around the Kutabumi area, Tangerang Banten, a total of 20 people, preferably housewives and young women who want to understand more deeply the study of Islamic household financial management.

The activity methods to be used are as follows:

1). Extension methods; used forconvey material in the form of theory.

2). Question and answer method; used to provide opportunities for participants who are not yet clear in their understanding;

3). Method Demonstration; Implementation Islamic spending and consumption patterns

4). Exercise/Practice Methods; Examples of Islamic household financial management

\section{RESULTS AND DISCUSSION}

This Community Service Program is carried out in the following forms:

1). Counseling; convey material in the form of theory.

2). Question and answer; provide opportunities for participants who are not clear in their understanding;

3). Demonstration; Implementation good islamic financial planning

4). Exercise/Practice; Example of Islamic household financial planning

The flow of financial planning practice:

1) The preparation stage, which consists of the following stages:

a) preparation of materials in accordance with the needs of the implementation of activities,

b) coordinate with residents of Tanjung Duren Barat Village, West Jakarta,

c) prepare activity theory material, and

d) prepare a schedule of activities for 1 effective day,

2) The implementation stage, which consists of:

a) Providing good Islamic financial planning counseling

b) Provide opportunity for question and answer for participants who are not clear in their understanding

3) Evaluation stage, which consists of:

a) Presentation of the results of the Islamic financial planning exercise

b) Implementation Islamic family financial planning

In this Community Service, our team is more focused on understanding financial management from an Islamic point of view and providing counseling to students residents of Tanjung Duren Barat Village, West Jakarta. Wthe price of Tanjung Duren Barat Village, West Jakarta briefed on how to do good Islamic family financial planning, including:

\section{Making postal notes}

Make a note of spending plans in one month. For example, in the next month, there will be expenses for food, house installments, vehicle payments, children's school fees, savings, insurance, and recreation money. Write down the priority scale from the most important to the additional needs. From the list you will see approximately how much money you have to spend each month. First, allocate it for important purposes, then allocate it for secondary purposes.

2. Saving early earn money

One thing you're so forth doing is saving. Make a special allocation of savings funds. Create a special savings fund and set it aside at the beginning of the month. Determine the amount and immediately save it in a special account. This account should not be mixed with daily accounts so as not to be confused and not tempted to use the saved money for daily needs.

3. Discussion with spouse and children

Discuss financial problems with children and spouse. Do not cover up financial problems from the family. For example, if there is an additional need for school fees, then the recreation allowance must be removed first. This must also be discussed with children, not only with your partner. usually associated with the whole family.

4. Earn extra money

If your income is mediocre, then it's a good idea to look for additional money. There are many ways to earn extra money, for example buying and selling goods online.

5. Make a long term plan

Making long-term plans is important to do. For example, you are going home and vacation next year, so you have to plan from now on. Likewise, plans to send children to school must be planned in advance. You can raise these funds by saving or other investments such as mutual funds or buying gold. Also prepare an emergency fund so that your long-term plans don't fall apart, if at any time there is a sudden need.

\section{CONCLUSIONS AND SUGGESTIONS}

The conclusions of this activity are:

1. The Islamic family financial planning that we have organized has been able to provide additional knowledge to the students residents of Tanjung Duren Barat Village, West Jakarta regarding good Islamic family financial planning.

2. This activity was responded very positively by the participants, it was seen from their enthusiasm by asking many questions about the real daily financial planning in their families and the participants requested that this understanding and training be continued and held in the coming semester by leading to the detailed bookkeeping process.

This training activity should be carried out continuously for the same participants until they understand and can implement it. Seeing the benefits of 
this training which is quite large, it is better if the target audience is expanded not only in one kelurahan, but there are other kelurahan to follow

\section{REFERENCES}

http://pengusahamuslim.com/menelola-keuanganrumah-tang-yang-1850/\# Downloaded April 10, 2020

http://mirajnews.com/id/article/tausiyah/peranWanita-dalam-Menelola-Keuangan- Keluarga/ Downloaded April 10, 2020
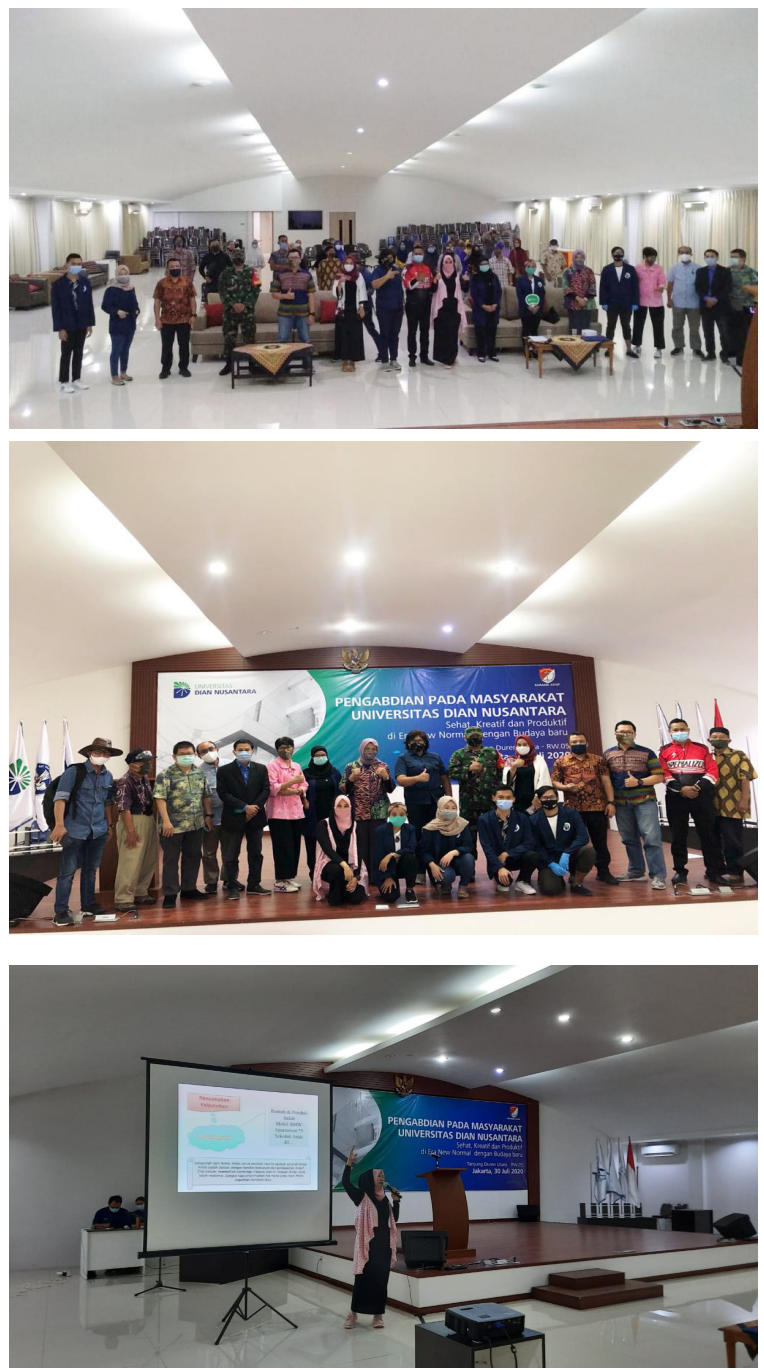

http://www.ayahbunda.co.id/family-keuangan/carasimplistic-managing-keuangan-family

On Download April 10, 2020

http://download.portalgaruda.org/article. val $=5460 \&$ title $=$ MANAGEMENT\%20 K E U A N G A N \% 20 D A L A M \% 20 KELUARGA\%20DARI\%20SUDUT\%20 PANDANG\%20ISLAM
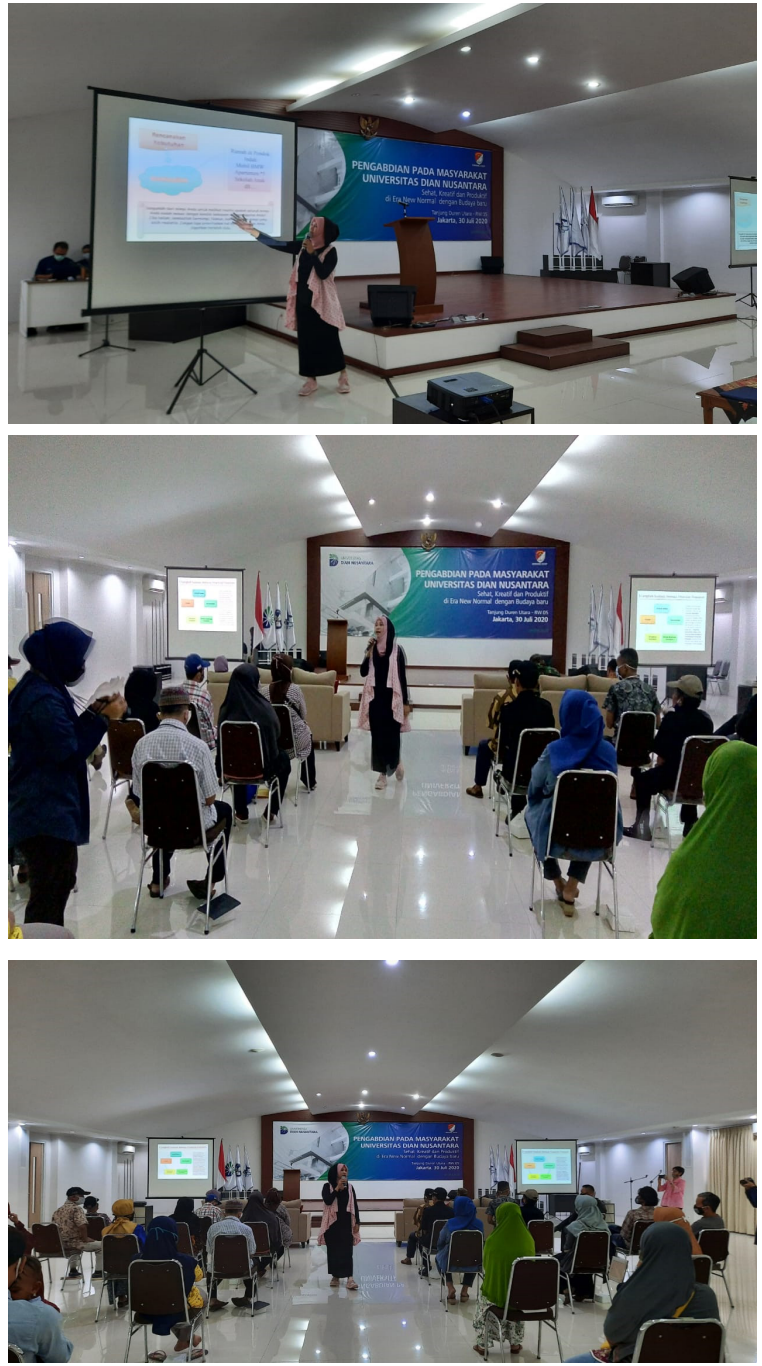